\title{
Tourism statistics, indicators and big data: a perspective article
}

\author{
Serena Volo
}

Serena Volo is based at the Faculty of Economics and Management, Free University of Bozen, Brunico, Italy.
Received 23 June 2019 Revised 25 September 2019 3 October 2019 Accepted 4 October 2019

(C) Serena Volo.Published by Emerald Publishing Limited. This article is published under the Creative Commons Attribution (CC BY 4.0) licence. Anyone may reproduce, distribute, translate and create derivative works of this article (for both commercial and non-commercial purposes), subject to full attribution to the original publication and authors. The full terms of this licence may be seen at http:// creativecommons.org/licences/ by/4.0/legalcode

\begin{abstract}
Purpose - This paper aims to discuss the evolution of tourism data and critically debates future perspective for producers and users of tourism data.

Design/methodology/approach - This paper provides a perspective on tourism data based on selected literature.

Findings - Industry developments, technological changes and novel methodologies have influenced tourism data sources. Closer attention to new data collection methods and novel analytics is required.

Research limitations/implications - A considerate and integrated system of tourism data (statistics, indicators, and big data) shall remain a priority for scholars and practitioners alike.

Practical implications - The thoughtful merging of tourists' digital traces with industry data, the competences of data analysts and the theoretical strengths of tourism scholars will result in a redesign of the tourism data landscape.

Social implications - This perspective article provides a brief overview of the development and challenges related to the future use of tourism statistics, indicators and big data.

Originality/value - The paper offers a novel vision of tourism data by combining three different but complementary aspects of tourism data.
\end{abstract}

Keywords Tourism statistics, Data sources, Tourism measurement, Index, Big data

Paper type Research paper

\section{Introduction}

The role of tourism data in assisting tourism planners and decision-makers in evaluating performances, setting targets and anticipating future scenarios has been widely acknowledged by scholars (Smith, 1988; Latham and Edwards, 2003; Volo, 2018). This contribution aims at the following:

- Discussing the evolution of tourism data sources spanning from the traditional collection of tourism supply and demand statistics to the exploitation of big data; and

- Presenting and debating future perspective for producers and users of tourism data.

\section{Past perspective: 75 years of developments (1946-2020)}

The need for tourism supply and demand statistics is well documented. Past literature indicates some of the usages of tourism data, such as:

- governments' evaluation of tourism dimension and its significance to the national economy;

- destinations' forecasts of tourism arrivals; and

- industry's decision-makers use for strategic marketing purposes (Wöber, 2000; Massieu, 2001; Volo, 2004). 
The collection of tourism statistics started, in most European countries, after the Second World War, and the first systematic collection of international travel statistics was the one published by the British Travel Association in 1949 (Lickorish, 1997). Tourism also attracted scientists' attention enabling, 75 years ago, the foundation of the first international scientific journal Tourism Review, which remains an authoritative source (Laesser et al., 2019). In 1973, the European Travel Commission issued a program for tourism statistics, soon after the World Tourism Organization proposed its guidelines. To date, the United Nation World Tourism Organization (UNWTO) publications provide technical guidance in the collection and use of tourism statistics (UNWTO, 1994, 2008). Initially, statistics were used mostly with the focus of defining tourism (Frechtling, 1976; Smith, 1988; Pine, 1992; Hannigan, 1994). Provocative contributions (Shackleford, 1980; Lickorish, 1997; Volo and Giambalvo, 2008; Frechtling and Hara, 2016) have then raised a few issues and provided some initial guidance. Methodological aspects were discussed throughout the decades (Ritchie, 1975; Latham and Edwards, 2003; Liang et al., 2012; Aroca et al., 2017) and - as the collection of tourism statistics improved - academics, enterprises and governments have paid increasing attention to the creation and use of indicators. Demand and supply simple indicators have permeated tourism literature over the past 50 years. In the past few decades, composite tourism indicators have addressed more complex issues such as competitiveness, sustainability and innovation (Gooroochurn and Sugiyarto, 2005; Volo, 2005; Pulido and Sanchez, 2009; Castellani and Sala, 2010). However, many indicators still suffer from the following:

- the deficiencies in systematically collect the necessary elementary data; and

- the difficulties in accounting for the complex nature of tourism which requires suitable operationalization and measurements of the investigated constructs (Mazanec et al., 2007; Volo, 2015; Mendola and Volo, 2017).

Thus, despite the recent developments, the contribution of composite indicators to comprehensive theoretical frameworks and the actual usage - by tourism stakeholders and operators - of the derived rankings remain often unclear and undocumented (Volo, 2018).

\section{Future perspective: 75 years of outlook (2020-2095)}

In the midst of these challenges, novel forms of measurements of tourism activities are emerging (Volo, 2018). Big data - namely extremely large or complex data set - have recently entered the realm of data sources for various aspects of human activities that can be digitally traced. The debate on the characteristics and exploitation of big data in tourism is quite extensive (Önder et al., 2016; Li et al., 2018; Mariani et al., 2018). Indeed, unstructured and often unofficial, big data are valuable for scholars and industries alike, as they allow to trace individual tourist's preferences, behaviors, points of interest, movements and even expenditures (Volo, 2018). Scholars are currently exploring big data sources to:

- exploit these powerful data as measurements of tourist flows in space and time (Hallo et al., 2012; Scaglione et al., 2016);

- predict tourism demand (Bangwayo-Skeete and Skeete, 2015; Song and Liu, 2017); and

- assess their validity as data sources (Mariani and Borghi, 2018; Mariani et al., 2019).

Along the same lines, a Eurostat task force has investigated the use of big data in complementing official statistics, including tourism statistics (Eurostat, 2014). The full potential of big data is under investigation, clearly the potential to induce real-time 
marketing actions (Buhalis and Sinarta, 2019) is appealing to tourism stakeholders, while scholars acknowledge the need for proper data mining and ad hoc algorithms to enable accurate use of these digital traces (Scaglione et al., 2016; Mariani et al., 2018).

Fast raising opportunities to use novel data sources impose few basic considerations for their successful integration as tourism data, as evident in Figure 1.

A basic system of tourism statistics is lacking in several countries - mostly the underdeveloped - thus significant work is needed, as these countries are receiving an increasing share of international tourism. The recent developments in the creation of composite indicator for tourism will continue but will need further strengthening and integration between traditional statistics and big data. Creating shared databases and replicable methods will allow scholars across countries to apply indicators to destinations of different magnitude enabling policymakers to easily access and soundly use these indicators. Meanwhile, tourists traces have become an invaluable source of data, and the emerging smart disruptive innovations in tourism will allow even more gathering of tourism-related big data and thus the need for reciprocity and fairness in data and information exchanges will be paramount (Buhalis et al., 2019). Legal and ethical exploitation of these novel data sources ought to be investigated, and pathways for mutual beneficial usage of scholars and businesses shall be designed. The challenges of data sharing, data extraction and data analytics have been explored albeit in an incomplete and fragmented way; thus, conceptual frameworks ought to be developed to ensure theory building and enhance customization and intelligent service supply (Mariani et al., 2018). Improved data analytics will enable using big data for not only tourism online marketing, design and recommendations but also demand

\section{Figure 1 Tourism data: future perspectives}

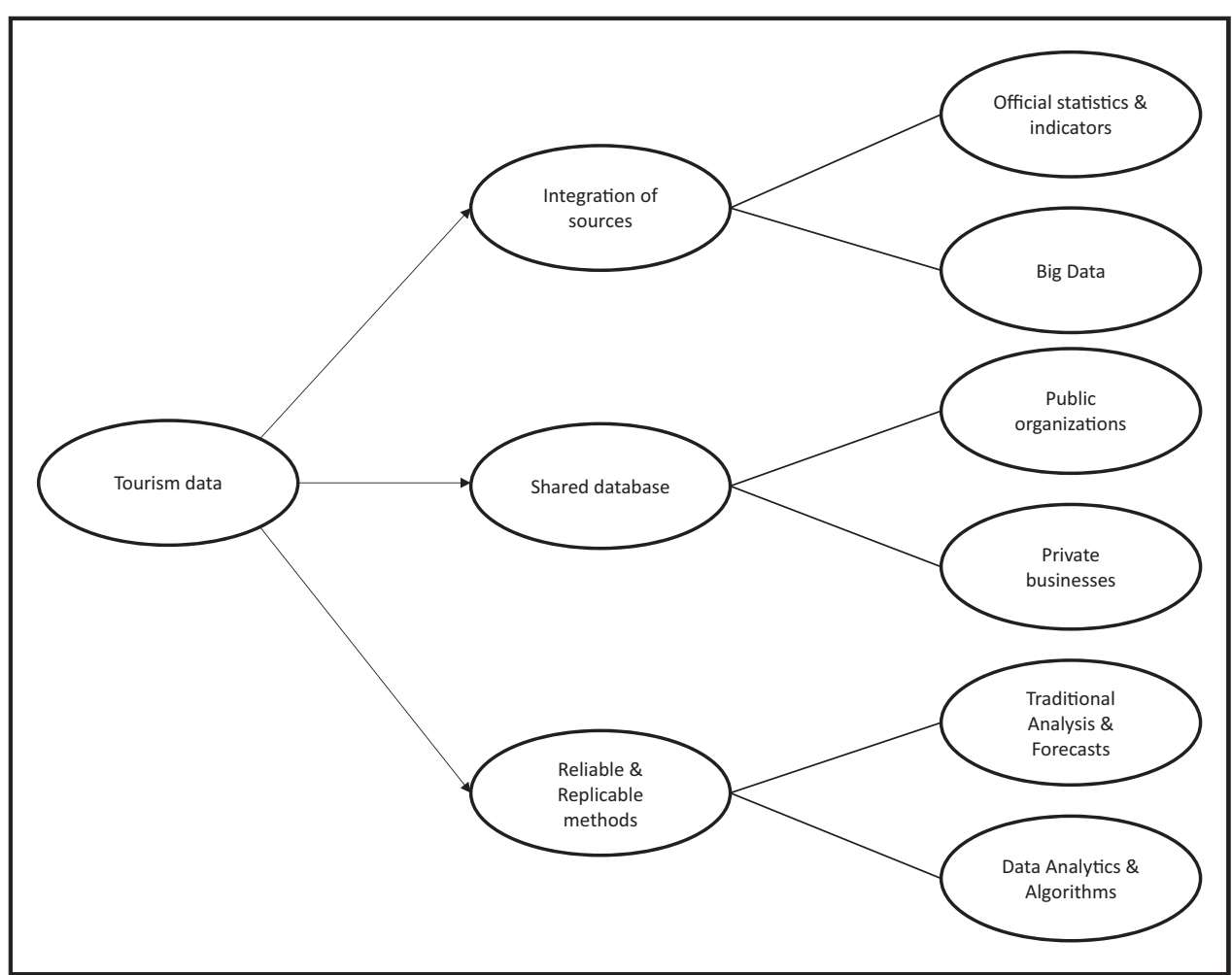


prediction, precaution and emergency studies ( $\mathrm{Li}$ et al., 2018). At the twilight of traditional measurements, tourism private and public stakeholders should foresee the enormous opportunity to combine, in real-time, information obtained by tourists' digital traces with that of tourism companies' databases and information systems. An exciting time to come for the tourism industry.

\section{Conclusions}

The slow development of tourism statistics, followed by the methodological scrutiny of those interested in indicators have left space to the disruption of big data. The challenge remains however on shifting the attention from a "big" to a "smart" usage of these data, adding layers of information, facilitating real-time usage and appropriate dissemination of trends. The thoughtful merging of tourists' digital traces with industry data, the competences of data analysts and the theoretical strengths of tourism scholars will results in a redesign of the tourism data landscape. A considerate and integrated system of tourism data (statistics, indicators and big data) shall remain a priority for scholars and practitioners alike.

\section{References}

Aroca, P., Brida, J.G. and Volo, S. (2017), "Tourism statistics: correcting data inadequacy", Tourism Economics, Vol. 23 No. 1, pp. 99-112.

Bangwayo-Skeete, P.F. and Skeete, R.W. (2015), "Can Google data improve the forecasting performance of tourist arrivals? Mixed-data sampling approach", Tourism Management, Vol. 46 No. 1, pp. 454-464.

Buhalis, D. and Sinarta, Y. (2019), "Real-time co-creation and nowness service: lessons from tourism and hospitality", Journal of Travel \& Tourism Marketing, Vol. 36 No. 5, pp. 563-582.

Buhalis, D., Harwood, T., Bogicevic, V., Viglia, G., Beldona, S. and Hofacker, C. (2019), "Technological disruptions in services: lessons from tourism and hospitality", Journal of Service Management, Vol. 30 No. 4, available at: https://dx.doi.org/10.1108/JOSM-12-2018-0398

Castellani, V. and Sala, S. (2010), "Sustainable performance index for tourism policy development", Tourism Management, Vol. 31 No. 6, pp. 871-880.

Eurostat (2014), "Feasibility Study on the Use of Mobile Positioning Data for Tourism Statistics", Eurostat.

Frechtling, D.C. (1976), Proposed Standard Definitions and Classifications for Travel Research, US Travel Data Center, New York, NY.

Frechtling, D.C. and Hara, T. (2016), "State of the world's tourism statistics and what to do about it", Tourism Economics, Vol. 22 No. 5, pp. 995-1013.

Gooroochurn, N. and Sugiyarto, G. (2005), "Competitiveness indicators in the travel and tourism industry", Tourism Economics, Vol. 11 No. 1, pp. 25-43.

Hallo, J.C., Beeco, J.A., Goetcheus, C., McGee, J., McGehee, N.G. and Norman, W.C. (2012), "GPS as a method for assessing spatial and temporal use distributions of nature-based tourists", Journal of Travel Research, Vol. 51 No. 5, pp. 591-606.

Hannigan, K. (1994), "Developing European community tourism statistics", Annals of Tourism Research, Vol. 21 No. 2, pp. 415-417.

Laesser, C., Bieger, T., Keller, P. and Buhalis, D. (2019), "75 Years of tourism review: survival by transformation: a perspective article", Tourism Review, Vol. 1, available at: https://doi.org/10.1108/TR-022019-0069

Latham, J. and Edwards, C. (2003), "The statistical measurements of tourism", in Cooper C. (Ed.), Classic Reviews in Tourism, Channel View Publications, Clevedon.

Li, J., Xu, L., Tang, L., Wang, S. and Li, L. (2018), "Big data in tourism research: a literature review", Tourism Management, Vol. 68 No. 2, pp. 301-323. 
Liang, C.J.H., Chen, H.B. and Wang, M.Y. (2012), "Units, populations, and valid analyses", International Journal of Culture, Tourism and Hospitality Research, Vol. 6 No. 1, pp. 70-80.

Lickorish, L.J. (1997), "Travel statistics - the slow move forward", Tourism Management, Vol. 18 No. 8 , pp. 491-497.

Mariani, M.M. and Borghi, M. (2018), "Effects of the booking.com rating system: bringing hotel class into the picture", Tourism Management, Vol. 66, pp. 47-52.

Mariani, M.M., Borghi, M. and Gretzel, U. (2019), "Online reviews: differences by submission device", Tourism Management, Vol. 70, pp. 295-298.

Mariani, M.M., Baggio, R., Fuchs, M. and Höpken, W. (2018), "Business intelligence and big data in hospitality and tourism: a systematic literature review", International Journal of Contemporary Hospitality Management, Vol. 30 No. 12, pp. 3514-3554.

Massieu, A. (2001), "A system of tourism statistics (STS): scope and content", in Lennon, J.J. (Ed.), Tourism Statistics, Continuum, London, pp. 3-13.

Mazanec, J.A., Wöber, K. and Zins, A.H. (2007), "Tourism destination competitiveness: from definition to explanation?", Journal of Travel Research, Vol. 46 No. 1, pp. 86-95.

Mendola, D. and Volo, S. (2017), "Building composite indicators in tourism studies: measurements and applications in tourism destination competitiveness", Tourism Management, Vol. 59 No. 2, pp. 541-553.

Önder, I., Koerbitz, W. and Hubmann-Haidvogel, A. (2016), "Tracing tourists by their digital footprints: the case of Austria”, Journal of Travel Research, Vol. 55 No. 5, pp. 566-573.

Pine, R.J. (1992), "Towards a useful measure of tourism activity at individual country level", Tourism Management, Vol. 13 No. 1, pp. 91-94.

Pulido, I.J. and Sanchez, M. (2009), "Measuring tourism sustainability: proposal for a composite index", Tourism Economics, Vol. 15 No. 2, pp. 277-296.

Ritchie, J.R.B. (1975), "Some critical aspects of measurement theory and practice in travel research", Journal of Travel Research, Vol. 14 No. 1, pp. 1-10.

Scaglione, M., Favre, P. and Trabichet, J.-P. (2016), "Using mobile data and strategic tourism flows: pilot study monitour in Switzerland", Proceedings of the Big Data in Tourism \& Business Intelligence in the Travel \& Tourism Domain, Mid Sweden University, pp. 69-72.

Shackleford, P. (1980), "Keeping tabs on tourism: a manager's guide to statistics", International Journal of Tourism Management, Vol. 1 No. 3, pp. 148-157.

Smith, S.L.J. (1988), "Defining tourism a supply-side view", Annals of Tourism Research, Vol. 15 No. 2, pp. 179-190.

Song, H. and Liu, H. (2017), "Predicting tourist demand using big data", in Xiang, Z. and Fesenmaier, D.R. (Eds), Analytics in Smart Tourism Design, Springer, Cham, pp. 13-29.

UNWTO (1994), Recommendations on Tourism Statistics, 1994 Edition Madrid: World Tourism Organization, https://unstats.un.org/unsd/publication/Seriesm/SeriesM_83e.pdf.

UNWTO (2008). OECD (2008), International Recommendations for Tourism Statistics 2008 (IRTS 2008), New York, Madrid, United Nations, Statistical Office of the European Communities; Organisation for Economic Co-operation and Development; and World Tourism Organization.

Volo, S. (2004), "A journey through tourism statistics: accuracy and comparability issues across local, regional and national levels", Proceedings of the 24th Biennial Conference on Regional and Urban Statistics: Understanding Change (SCORUS), Minneapolis, MN, pp. 210-216.

Volo, S. (2005), "A consumer-based measurement of tourism innovation", Journal of Quality Assurance in Hospitality \& Tourism, Vol. 6 Nos 3/4, pp. 73-87.

Volo, S. (2015), "Indicator", in Cater, C., Garrod, B. and Low T. (Eds), The Encyclopedia of Sustainable Tourism, CABI, Oxford, pp. 277-279.

Volo, S. (2018), "Tourism data sources: from official statistics to big data", in Cooper, C., Volo, S., Gartner, W.C. and Scott, N. (Eds), The SAGE Handbook of Tourism Management, SAGE, London, pp. 193-201. 
Volo, S. and Giambalvo, O. (2008), "Tourism statistics: methodological imperatives and difficulties: the case of residential tourism in island communities", Current Issues in Tourism, Vol. 11 No. 4, pp. 369-380.

Wöber, K.W. (2000), "Standardizing city tourism statistics", Annals of Tourism Research, Vol. 27 No. 1, pp. 51-68.

\section{About the author}

Serena Volo is Associate Professor at the Faculty of Economics and Management, Free University of Bozen, Italy. Her research interests include consumer behavior in tourism, tourism statistics and indicators, tourism big data analytics, destination competitiveness and innovation. Serena Volo can be contacted at: SVolo@unibz.it

For instructions on how to order reprints of this article, please visit our website: www.emeraldgrouppublishing.com/licensing/reprints.htm

Or contact us for further details: permissions@emeraldinsight.com 